\title{
Effects of Quercus rubra L. on soil properties and humus forms in 50-year-old and 80-year-old forest stands of Lombardy plain
}

\author{
Chiara Ferré ${ }^{1}$ (D) $\cdot$ Roberto Comolli ${ }^{1}$
}

Received: 9 June 2019 / Accepted: 11 October 2019 / Published online: 10 January 2020

(C) INRA and Springer-Verlag France SAS, part of Springer Nature 2020

\begin{abstract}
- Key message Besides the well-known effects on the native plant community, red oak may also impact the soil; the effects of afforestation with red oak involve both organic layers and mineral soil, resulting in changes in organic carbon quantity and quality and in soil acidification.

- Context Many alien species have become widespread in Europe; among these, red oak is a common invader of temperate forests.

- Aims The effects of substitution of natural mixed forest by red oak forest on humus forms and soil properties were investigated in two paired plots: a 50-year-old (Bosco Vacaressino) and 80-year-old (Bosco Ginestre) forest stand.

- Methods Soil sampling was performed from 3 layers at 40 and 49 points in Bosco Vacaressino and Bosco Ginestre respectively to determine humus forms, soil $\mathrm{pH}$, organic carbon stock, carbon-nitrogen ratio $(\mathrm{C}: \mathrm{N})$, available phosphorus, and texture.

- Results Red oak resulted in a shift from Mull to Moder humus forms; soil acidification, higher C:N ratio, and soil organic carbon stock were observed compared with mixed forests.

- Conclusion The major changes were reflected in a change toward less active humus forms; the effects of vegetation conversions were also visible in mineral layers; many of the modifications were more evident with increasing stand age.
\end{abstract}

Keywords Alien species $\cdot$ Red oak $\cdot$ Forest Conversion $\cdot$ Humus form $\cdot$ Soil spatial variability $\cdot$ Mixed model

\section{Introduction}

Alien invasive plant species have significant effects on the structure and function of ecosystems (Ehrenfeld 2003; Hejda et al. 2009). Invasive species can threaten biological diversity in particular by reducing genetic variation through the endangering of endemic species and by altering habitat and ecosystem functioning. Because of human intervention, many alien species have become widespread in Europe in the last century;

Handling Editor: Andreas Bolte

Contribution of the co-authors The authors have equally contributed.

Chiara Ferré

chiara.ferre@unimib.it

Roberto Comolli

roberto.comolli@unimib.it

1 Department of Earth and Environmental Sciences, Milano Bicocca University, Milan, Italy among these, red oak (Quercus rubra L.) is a common invader of European temperate forests. Native to North America, red oak was introduced in Europe in the eighteenth century as timber species and ornamental plant. Red oak grows up to $60 \%$ faster than common oak (Quercus robur L.) and sessile oak (Quercus petraea (Matt.) Liebl.) (Magni Diaz 2004; Vansteenkiste et al. 2005), flourishes in acidic conditions, and may tolerate compacted and periodically flooded soils; a thick litter layer protects the acorns against decay and inhibits the renewal of other tree species.

Compared with the extensive literature on the effects of invasive species on native plant community, structure, and understory environment (Chmura 2013; Hejda et al. 2009; Lenda et al. 2013; Vilà et al. 2011), studies on the impact of red oak on soil properties are still limited and provided sometimes conflicting results (Bonifacio et al. 2015; Miltner et al. 2016; Riepsas and Straigyte 2008; Stefanowicz et al. 2017). Unlike vegetation dynamics, which occur rapidly and are easily observable and interpretable, the understanding of soil dynamics and processes is complex, getting more difficult the formation of any generalizations on the invasion influence on soil. The great spatial 
variability in pedological and pedoclimatic parameters and the need to have a high number of samples to significantly characterize these parameters generate additional issues in understanding soil dynamics.

Vegetation affects soil characteristics mainly through litterfall, root turnover, and exudation of different compounds. The rate of decomposition of plant residues and the incorporation of organic matter in mineral horizons depend on forest types. In a forest ecosystem, the humus form derives from the equilibrium between litter production, decomposition, and humification, resulting from the biological action of bacteria, fungi, and soil fauna. The diversity of humus forms may be related to the adoption of different strategies for the acquisition and use of resources by ecosystems (Ponge 2003). It follows that the humus form can act as a field indicator of environmental variations, such as substitution of vegetation.

In northern Italy, mesophytic mixed oak forests are among the most threatened by artificially introduction of red oak, which rapidly spreads due to its ability to compete with shade-tolerant species, to quickly grow and resist to disease and water stress.

We assumed that the presence of red oak may modify soil characteristics starting from the organic layers and deepening with the duration of its permanence. The aim of this work was to evaluate and quantify the impact of such alien plant on humus forms and soil properties, considering variability in soil characteristics; we present here the results of two paired plot studies in the Lombardy plain (Italy), comparing natural mixed forests representing the original vegetation of the Po Valley with 50- and 80year-old red oak stands.

\section{Material and methods}

\subsection{Study sites}

The two study sites were Bosco Vacaressino (at $45^{\circ} 20^{\prime} 47^{\prime \prime} \mathrm{N}$, $8^{\circ} 56^{\prime} 37^{\prime \prime}$ E, elevation $94 \mathrm{~m}$ a.s.l.) and Bosco Ginestre (at $45^{\circ}$ $20^{\prime} 39^{\prime \prime} \mathrm{N}, 8^{\circ} 55^{\prime} 18^{\prime \prime} \mathrm{E}$, elevation $87 \mathrm{~m}$ a.s.l.); they are located within the Parco Regionale del Ticino, Italy, near Morimondo and about $7 \mathrm{~km}$ northwest of the city of Vigevano. The distance between the sites is $1700 \mathrm{~m}$ (Fig. 1).

The soils, developed on alluvial deposits of the Ticino River, show a limited degree of pedogenesis (Tables 2 and 3 in Annex 2; Fig. 5 in Annex 1): according to the World Reference Base (WRB) classification (IUSS Working Group WRB 2015), they are Regosols, Umbrisols, and Cambisols, rich in organic matter and desaturated in bases at the surface, but tending to saturation in depth, with coarse sandy texture at the surface and often with abundant gravel in depth. From pedogenetic point of view, less evolved soils (Regosols) are found on younger surfaces (Bosco Ginestre, recent alluvial terrace), and most evolved ones (Cambisols), which show cambic horizon, are found on older surfaces (Bosco Vacaressino, ancient alluvial terrace). The climate is temperate continental, as monitored by the meteorological station at Vigevano (1970-2015), with yearly average rainfall of $1032 \mathrm{~mm}$ (maximum in October-November, minimum in January-February) and mean air temperature of 11.3 ${ }^{\circ} \mathrm{C}$. As the water reserve of the soil (AWC) is low (shallow soils, coarse texture), in the warmer years with little rain (e.g., 2015), the water deficit can be high (Fig. 6 in Annex 1).

The natural land cover of the area is Padanian-Illyrian hardwood forest in transition to mesophytic Padanian mixed oak forest (Bohn et al. 2000). The landscape was mostly forested (dominated by deciduous oaks, Quercus spp., and hornbeam (Carpinus betulus L.) until late Middle Age clearings (Ravazzi et al. 2013). Currently, a few areas have maintained the past forest cover that has not been replaced by agricultural crops and, according to historical and cadastral documents (dating back to 1722: Teresian Cadastre), has never changed, at least in the last 300 years.

Mixed forest (MF) is nowadays dominated by common oak and hornbeam; in the shrub layer, there are common hazel (Corylus avellana L.), black cherry (Prunus serotina Ehrh.), wild cherry (Prunus avium L.), black locust (Robinia pseudoacacia L.), spindle (Euonymus europaeus L.), and elder (Sambucus nigra L.); periwinkle (Vinca minor L.) and lily of the valley (Convallaria majalis L.) are often present in the herbaceous layer.

In some parts of the study sites, red oak was introduced in order to take advantage of its rapid growth and disease resistance, resulting in the creation of red oak forest spots where native species were completely replaced, surrounded by mixed forest. In the two study sites, it was therefore possible to investigate the effect of red oak on soils by comparing data with neighboring mixed forest areas.

The vegetation of the red oak forests is dominated in the tree layer by red oak trees of about 50 years (Bosco Vacaressino) and 80 years (Bosco Ginestre), as estimated by dendrochronological analyses on collected increment cores using a Pressler borer. Red oak stands are dominant in the vigorous rejuvenation layer too, where there is also common hawthorn (Crataegus monogyna Jacq.), common hazel, black locust, and black cherry; among the herbs, red bracken (Pteridium aquilinum $\mathrm{L}$.) is often present.

At Bosco Vacaressino, the mixed forest zone is separated from the red oak forest by a relict riverbed, about $20 \mathrm{~m}$ wide, which is constantly humid and without trees. 

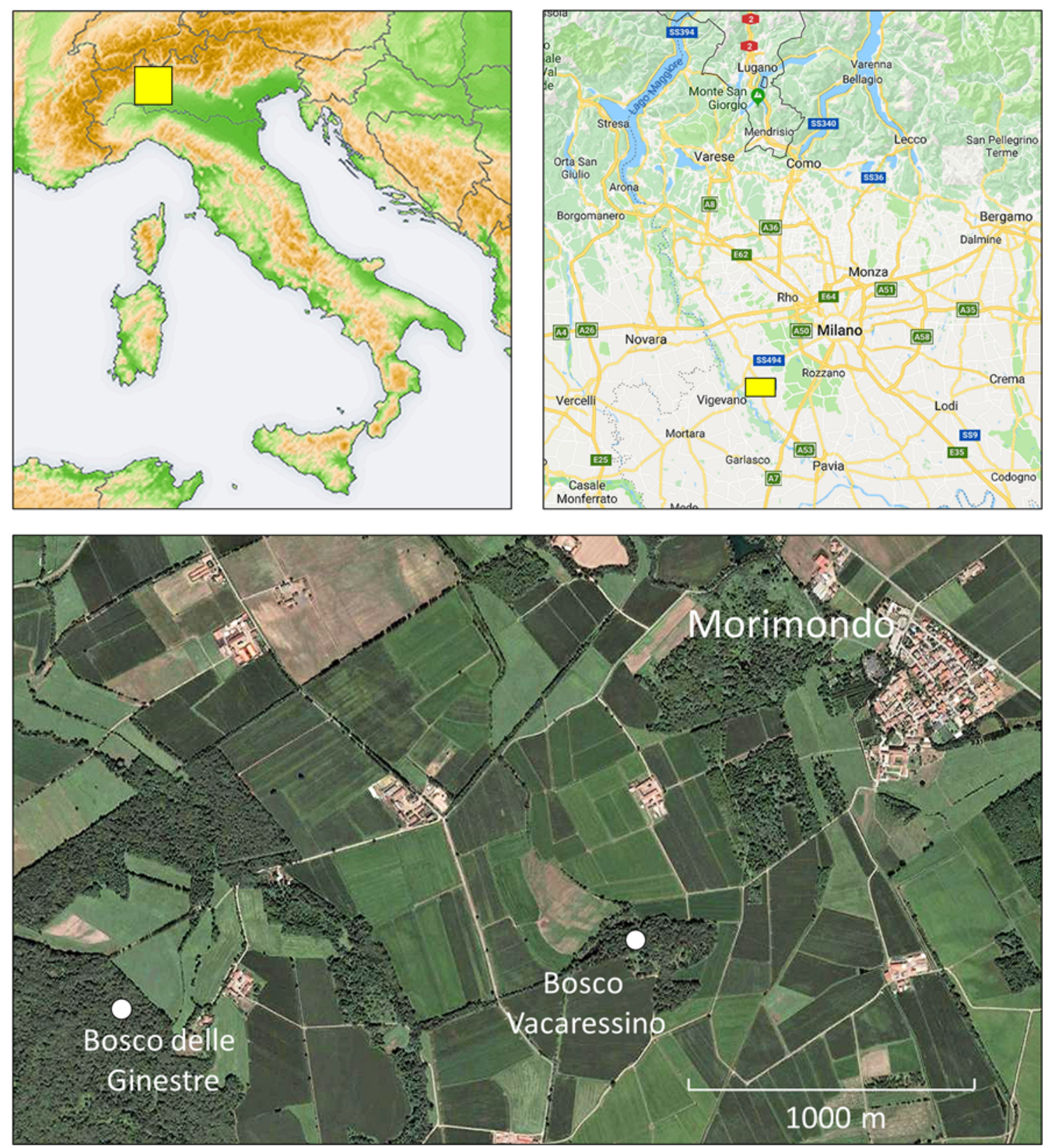

Fig. 1 Study sites: Bosco Vacaressino (BV) and Bosco Ginestre (BG)

\subsection{Sampling and analyses of organic horizons and mineral layers}

The effects of conversions from mixed to red oak forest were investigated by sampling and comparing neighboring forests. Humus forms and soil properties were assessed accounting for site spatial variability. Due to the albeit limited variability in thickness and typology of mineral soil horizons, sampling by layers (3 layers) was chosen.

Sampling was performed using a cylindrical core sampler (5.4-cm diameter) for the first two layers and a gouge auger (Eijkelkamp; 2.5-cm diameter) for the deeper layer. The first layer was chosen because it corresponded to the surface portion of soil, rich in organic matter and more involved by the change of vegetation cover, the last one as apparently not involved in the conversion and the intermediate layer to evaluate the vertical trend of the impact; for the two study sites, different layer thicknesses were identified, basing on characteristics of representative pedological pits (Table 2 in Annex 2).

At Bosco Vacaressino, sampling was performed during summer 2015 over an area of about 2 ha, at 40 (20 for each forest type) georeferenced sampling points based on a random scheme. According to soil pit description, for this study area, the 3 investigated layers were as follows: $0-10 \mathrm{~cm}$ 
(corresponding approximately to $\mathrm{A}$ and $\mathrm{AB}$ horizons), 10-30 $\mathrm{cm}$ (corresponding to $\mathrm{AB}$ and $\mathrm{Bw}$ horizons), and 30-60 cm (corresponding to $\mathrm{BC}$ horizon).

At Bosco Ginestre, the sampling was performed during late summer 2014 over a total area of about 2 ha. Soil samples were collected at 49 (20 at mixed forest and 29 at red oak forest) randomly selected georeferenced points, from 3 layers: 0-10 cm (corresponding approximately to A horizon), 10-35 $\mathrm{cm}$ (mainly corresponding to transition AC horizons), and 35$60 \mathrm{~cm}$ (corresponding to $\mathrm{C} 1$ and $\mathrm{C} 2$ horizon).

The coring survey was carried out to uniformly assess the impact of forest conversion by comparing equivalent soil volumes and, concerning soil stock only, equivalent soil masses; in fact, in this study, $\mathrm{SOC}_{\text {stock }}$ was compared between the different forest types by evaluating equivalent masses (Poeplau et al. 2011), accounting for differences in soil BD since major errors have been found in quantifying changes in $\mathrm{SOC}_{\text {stock }}$ to fixed depth compared with quantification in equivalent soil mass (Ellert and Bettany 1995). For each site, the largest soil masses (considering a thickness of 30 and $35 \mathrm{~cm}$ for Bosco Vacaressino and Bosco Ginestre respectively) were identified and considered as reference mass; all the soil masses in correspondence of the sampling points were then aligned to the reference mass.

Soil samples were air dried, sieved (2-mm mesh), and analyzed to determine soil organic carbon (SOC) and total nitrogen (TN) content (Flash EA 1112 NCSoil, Thermo Fisher Scientific elemental analyzer, Pittsburgh, PA, USA), $\mathrm{pH}$ in water (soil to water ratio of $1: 2.5$ ), particle-size distribution by sieving and sedimentation (Burt 2004) (sand, 0.05-2 mm; silt, 0.002-0.05; clay, $<0.002 \mathrm{~mm}$ ), for a total of 44 and 32 sampling points at Bosco Vacaressino and Bosco Ginestre respectively. Available phosphorus (Olsen et al. 1954) was determined in the $0-10 \mathrm{~cm}$ layer only. List and abbreviations of all investigated parameters are shown in Table 1.

For each monitoring point, soil bulk density (BD) was determined for the first two layers with the cylindrical core method (core diameter $5.4 \mathrm{~cm}$ ) on undisturbed core samples, considering the volume of stones, which were mainly absent or few at Bosco Ginestre and common (mean $\pm \mathrm{SD}, 12.3 \pm 4.7 \%$ ) at Bosco Vacaressino. Considering $\mathrm{BD}$ and stone volume, $\mathrm{SOC}_{\text {stock }}$ was computed on an area basis for mineral layers.

At each soil sampling point, humus form was described in the field and then classified according to Zanella et al. (2011, 2018), considering the presence and characteristics of OL, OF, and $\mathrm{OH}$ organic horizons and of A mineral horizon.

Organic horizons were sampled using a $30 \times 30 \mathrm{~cm}$ frame and the collected biomass was oven-dried at $70{ }^{\circ} \mathrm{C}$ for $48 \mathrm{~h}$ and weighed. The organic carbon content (OC) of organic horizons was determined by combustion with a muffle furnace at $550{ }^{\circ} \mathrm{C}$ for $4 \mathrm{~h}$ and converted to content on area basis $\left(\mathrm{kg} \mathrm{m}^{-2}\right)$.

The Humus Index (Hum $\left.{ }_{\text {ind }}\right)$, which was proposed and designed for the transformation of a scale of discrete humus forms in a numerical parameter (Ponge et al. 2002), was used; the humus forms were classified and scaled in order of increasing accumulation of organic matter in the $\mathrm{O}$ horizons and decreasing burrowing activity in the A horizon as follows: 1: Eumull (not present in our study sites), 2: Mesomull, 3: Oligomull, 4: Dysmull, 5: Hemimoder, 6: Eumoder, and 7: Dysmoder.

In text and figures, for the comparison between forest types, we used average values and standard deviations.

\subsection{Statistical analyses}

In order to evaluate the effects of forest conversion on soil properties and humus forms, the mixed effect model procedure was performed (Bolker et al. 2009), testing for autocorrelation among the model residuals (Searle et al. 2009). Each variable response in relation to forest type was evaluated considering forest type as a fixed effect in the linear mixed model. Statistical analyses were performed with PROC MIXED of SAS software package (release 9.4; SAS Institute) (Littell et al. 2006). The simultaneous estimates of covariance parameter and fixed effect coefficients were obtained by restricted maximum likelihood (REML) estimation (Littell et al. 2006). The spatial covariance function of residuals was determined iteratively using the statement REPEATED, by estimating partial sill, range, and nugget effect parameters. Residual spatial correlation was found for $\mathrm{SOC}_{1}, \mathrm{CN}_{1}$, and $\mathrm{CN}_{2}$ at Bosco Vacaressino and for $\mathrm{pHw}_{1}, \mathrm{SOC}_{\text {stock }}$, and $\mathrm{CN}_{1}$ at Bosco Ginestre.

If linear model assumptions on residuals distribution were not satisfied, as in the case of $\mathrm{pH}_{\mathrm{w}}$ of all three investigated layers at Bosco Vacaressino and of $\mathrm{OC}_{\mathrm{OF}}, \mathrm{OC}_{\mathrm{O}}$, and $\mathrm{CN}_{1}$ at Bosco Ginestre, Gaussian anamorphosis transformation of the response variable was performed using ISATIS software package (release 3.01; Geovariances, 2016).

\section{Results}

\subsection{Humus forms}

The main humus forms found at Bosco Vacaressino were, in order of decreasing biological activity according to $\mathrm{Hum}_{\text {ind }}$ (Ponge et al. 2002; Zanella et al. 2018): Mesomull, Oligomull, Dysmull, Hemimoder, and Eumoder. Mixed forest was characterized by Mull forms $\left(\right.$ Hum $\left._{\text {ind }} \leq 4\right)$ characterized by fast biodegradation and rapid disappearance of litter from the topsoil by mainly anecic and endogeic earthworms and bacteria, with prevalence of Mesomull, distinguished by the absence of OF horizon, followed by Dysmull and Oligomull. In the red oak forest besides Mull forms (mainly represented by Dysmull), Moder forms (Hum $_{\text {ind }}$ 5-6), where slower biodegradation by arthropods, 
Table 1 Investigated soil properties and their abbreviations

\begin{tabular}{|c|c|c|}
\hline Soil properties & Unit & Abbreviation \\
\hline Organic carbon stock of OL organic horizon & $\mathrm{kg} \mathrm{m}^{-2}$ & $\mathrm{OC}_{\mathrm{OL}}$ \\
\hline Organic carbon stock of OF organic horizon & $\mathrm{kg} \mathrm{m}^{-2}$ & $\mathrm{OC}_{\mathrm{OF}}$ \\
\hline Organic carbon stock of $\mathrm{OH}$ organic horizon & $\mathrm{kg} \mathrm{m}^{-2}$ & $\mathrm{OC}_{\mathrm{OH}}$ \\
\hline $\mathrm{OC}_{\mathrm{OL}}+\mathrm{OC}_{\mathrm{OF}}+\mathrm{OC}_{\mathrm{OH}}$ & $\mathrm{kg} \mathrm{m}^{-2}$ & $\mathrm{OC}_{\mathrm{O}}$ \\
\hline Soil organic carbon content of the $0-10 \mathrm{~cm}$ mineral soil layer & $\%$ & $\mathrm{SOC}_{1}$ \\
\hline Soil organic carbon content of the $10-30 \mathrm{~cm}$ or $10-35 \mathrm{~cm}$ mineral soil layer & $\%$ & $\mathrm{SOC}_{2}$ \\
\hline Soil organic carbon content of the $30-60 \mathrm{~cm}$ or $35-60 \mathrm{~cm}$ mineral soil layer & $\%$ & $\mathrm{SOC}_{3}$ \\
\hline Soil organic carbon stock of the $0-30 \mathrm{~cm}$ or $0-35 \mathrm{~cm}$ mineral soil layer & $\mathrm{kg} \mathrm{m}^{-2}$ & $\mathrm{SOC}_{\text {stock }}$ \\
\hline $\mathrm{C}: \mathrm{N}$ ratio of the $0-10 \mathrm{~cm}$ mineral layer & & $\mathrm{CN}_{1}$ \\
\hline $\mathrm{C}: \mathrm{N}$ ratio of the $10-30 \mathrm{~cm}$ or $10-35 \mathrm{~cm}$ mineral layer & & $\mathrm{CN}_{2}$ \\
\hline $\mathrm{C}: \mathrm{N}$ ratio of the $30-60 \mathrm{~cm}$ or $35-60 \mathrm{~cm}$ mineral layer & & $\mathrm{CN}_{3}$ \\
\hline $\mathrm{pH}$ in water of the $0-10 \mathrm{~cm}$ mineral layer & & $\mathrm{pH}_{\mathrm{w} 1}$ \\
\hline $\mathrm{pH}$ in water of the $10-30 \mathrm{~cm}$ or $10-35 \mathrm{~cm}$ mineral layers & & $\mathrm{pH}_{\mathrm{w} 2}$ \\
\hline $\mathrm{pH}$ in water of the $30-60 \mathrm{~cm}$ or $35-60 \mathrm{~cm}$ mineral layers & & $\mathrm{pH}_{\mathrm{w} 3}$ \\
\hline Available phosphorus content of the $0-10 \mathrm{~cm}$ mineral layer & $\mathrm{mg} \mathrm{kg}^{-1}$ & $\mathrm{P}_{\mathrm{av}}$ \\
\hline Humus index & & Hum $_{\text {ind }}$ \\
\hline Bulk density of the $0-10 \mathrm{~cm}$ mineral layer & $\mathrm{g} \mathrm{cm}^{-3}$ & $\mathrm{BD}_{1}$ \\
\hline Bulk density of the $10-30 \mathrm{~cm}$ or $10-35 \mathrm{~cm}$ mineral layers & $\mathrm{g} \mathrm{cm}^{-3}$ & $\mathrm{BD}_{2}$ \\
\hline
\end{tabular}

enchytraeids, and fungi resulted in the appearance of an $\mathrm{OH}$ horizon overlying a biomeso- or biomicrostructured A horizon, were found (Fig. 2).
At Bosco Ginestre, the humus forms found were as follows: Mesomull, Oligomull, Dysmull, Hemimoder, and Dysmoder (Fig. 2). Mixed forest was dominated by Mull

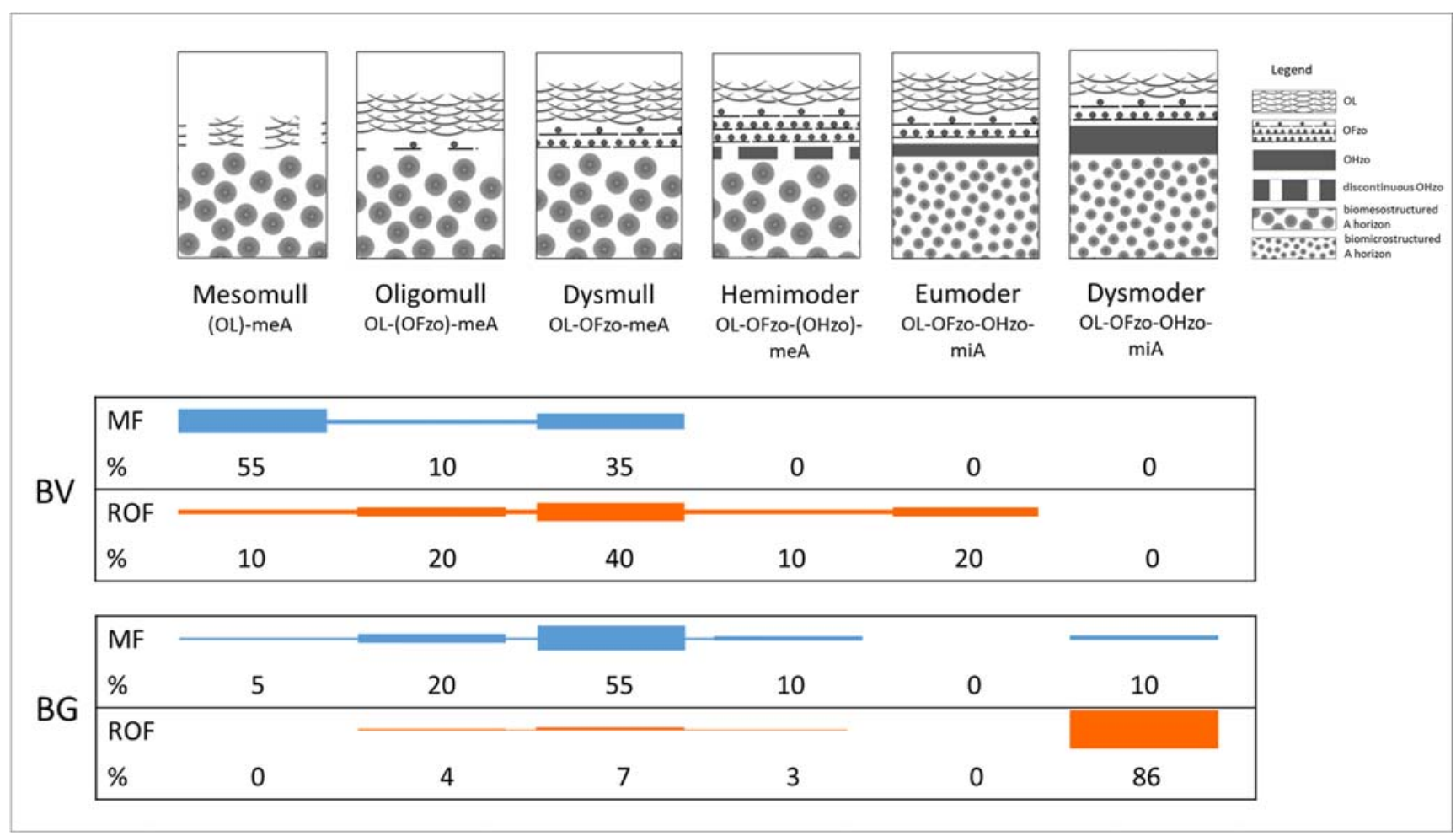

Fig. 2 Comparison of type and presence percentage of humus forms between natural mixed forest (MF) and red oak forest (ROF) types at Bosco Vacaressino (BV) and Bosco Ginestre (BG). zo: zoogenic horizon; meA: biomesostructured A horizon; miA: biomicrostructured A horizon 

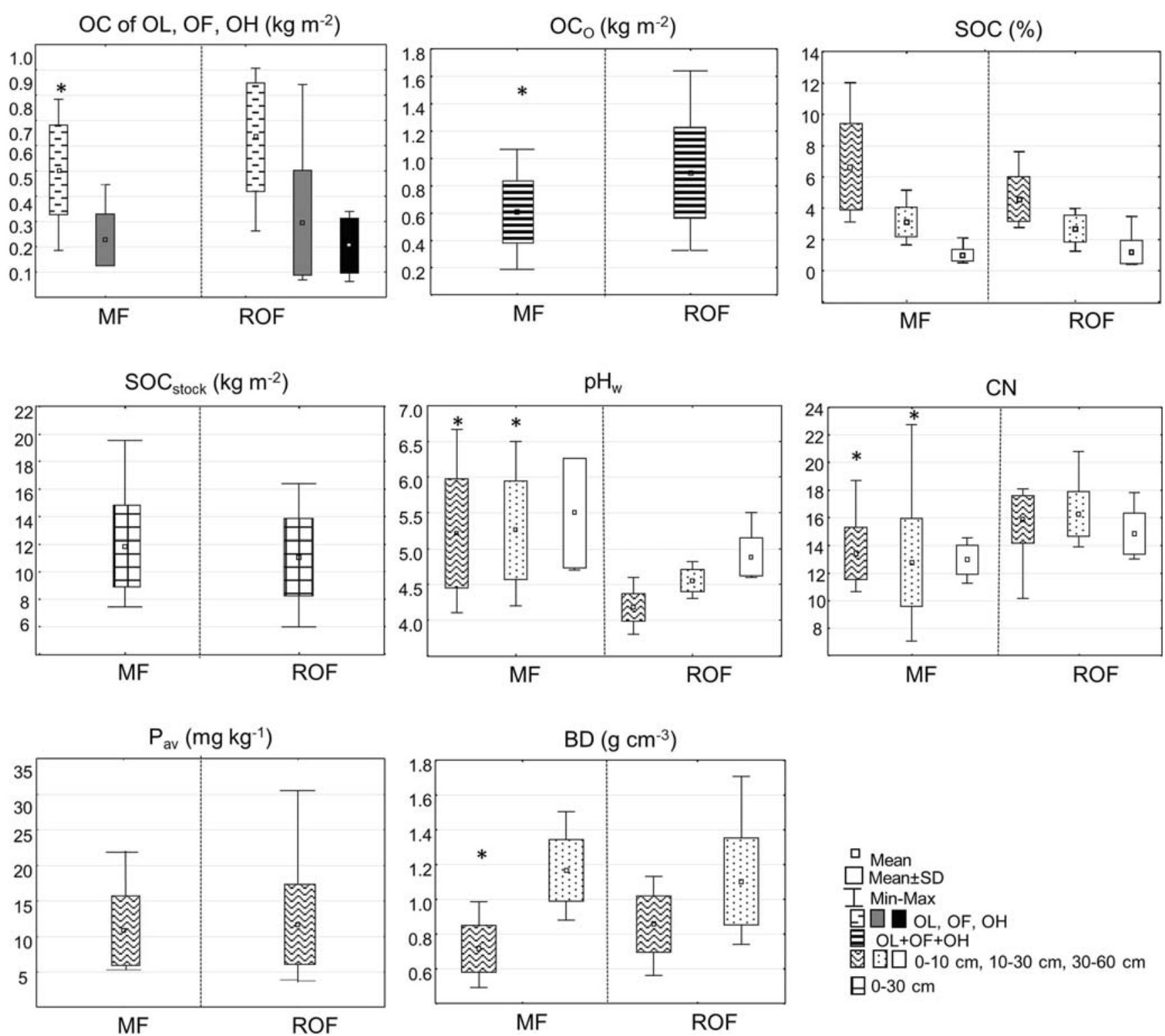

Fig. 3 Box plots for comparison of properties of organic and mineral layers between soil forest types (mixed forest, MF; red oak forest, ROF) at Bosco Vacaressino (BV). Asterisk indicates significant differences $(p<0.05)$ of response variable between forest types in the mixed model

forms $\left(\mathrm{Hum}_{\text {ind }} 2-4\right)$; the most represented Mull type was Dysmull with a continuous OF horizon overlying a biomesostructured A horizon. Dysmoder (Hum ind 7$)$ was the main humus form found in red oak forest (Fig. 2).

\subsection{Carbon stock of organic horizons}

At Bosco Vacaressino, $\mathrm{OC}_{\mathrm{OL}}$ was statistically higher in red oak forest compared with mixed forest, whereas no statistical differences in $\mathrm{OC}_{\mathrm{OF}}$ were found between the two forest types. The average $\mathrm{OC}_{\mathrm{OH}}$ of the thin or discontinuous $\mathrm{OH}$ horizon in the red oak forest was $0.21 \pm 0.11 \mathrm{~kg} \mathrm{~m}^{-2}$ (Fig. 3 and Tables 4 and 5 in Annex 2). In its entirety, the $\mathrm{OC}_{\mathrm{O}}$, obtained summing the $\mathrm{OC}$ of all the present organic horizons, was statistically higher in red oak forest compared with mixed forest for both study sites with differences between red oak forest and mixed forest more accentuated in Bosco Ginestre $\left(1.31 \mathrm{~kg} \mathrm{~m}^{-2}\right)$ than in Bosco Vacaressino $\left(0.28 \mathrm{~kg} \mathrm{~m}^{-2}\right)$.

At Bosco Ginestre, the average OC in red oak forest was $0.58 \pm 0.25 \mathrm{~kg} \mathrm{~m}^{-2}$ and $0.14 \pm 0.08 \mathrm{~kg} \mathrm{~m}^{-2}$ in $\mathrm{OL}$ and $\mathrm{OF}$ horizons, respectively, statistically higher $(p<0.05)$ than $\mathrm{OC}_{\mathrm{OL}}$ and $\mathrm{OC}_{\mathrm{OF}}$ of mixed forest (Fig. 4 and Tables 4 and 5 in Annex 2). The $\mathrm{OH}$ horizon of red oak forest showed an average $\mathrm{OC}_{\mathrm{OH}}$ of $1.28 \pm 1.05 \mathrm{~kg} \mathrm{~m}^{-2}$.

The variability in humus forms within each type of forest was reflected in the variability of the $\mathrm{OC}_{\mathrm{O}}$ : the coefficients of variation ranged from a minimum of $38 \%$ (Bosco Vacaressino) to a maximum of $65 \%$ (mixed 

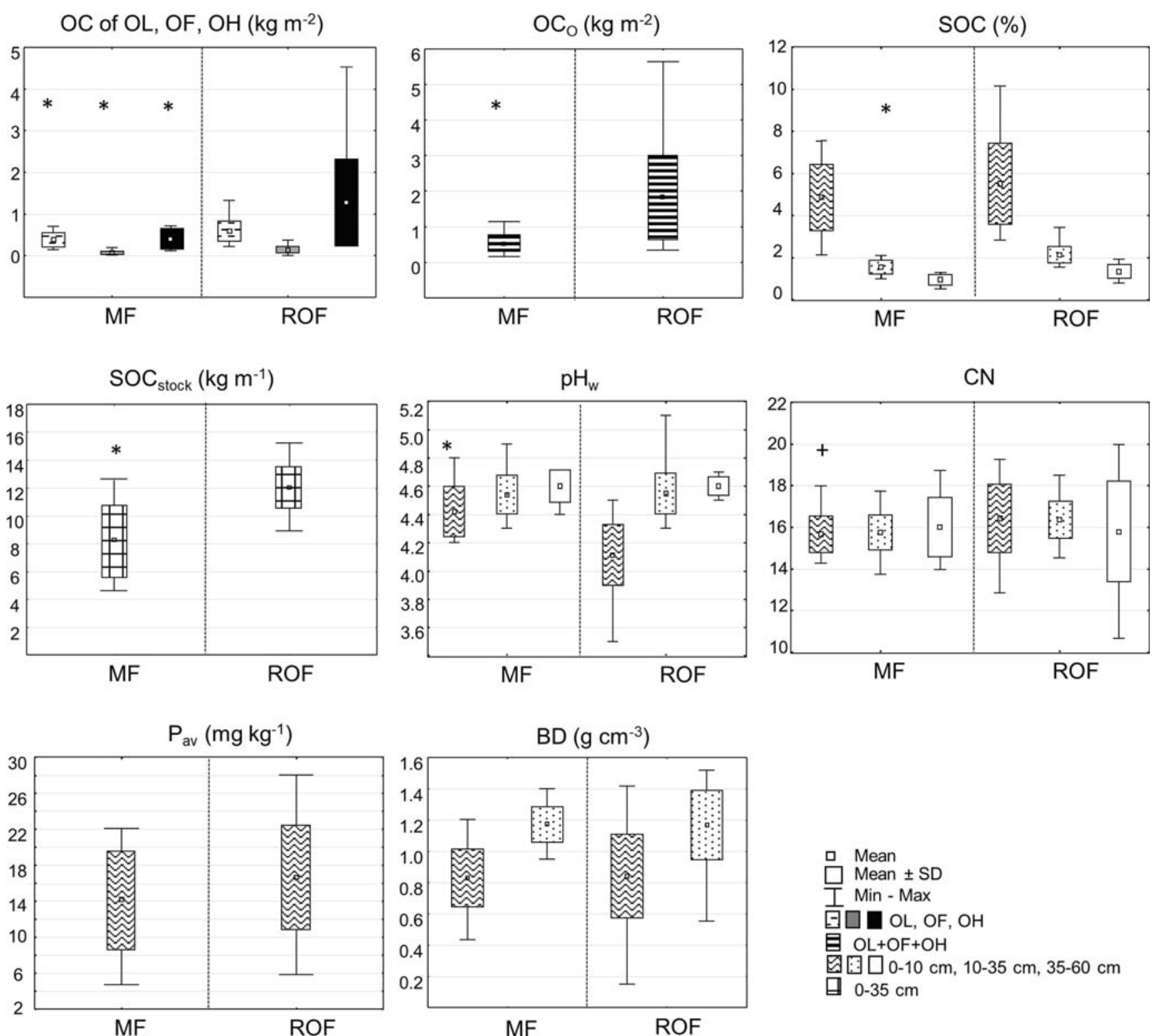

Fig. 4 Box plots for comparison of properties of organic and mineral layers between soil forest types (mixed forest, MF; red oak forest, ROF) at Bosco Ginestre (BG). Asterisk and plus sign indicate

significant differences $(p<0.05$ and $p<0.1$, respectively) of response variable between forest types in the mixed model

forest at Bosco Ginestre) with higher variations in $\mathrm{OF}$ and $\mathrm{OH}$ horizons than in OL horizons.

\subsection{Mineral soil}

In mixed forest at the Bosco Vacaressino site, the SOC averaged to $6.6 \pm 2.8 \%, 3.1 \pm 1.0 \%$, and $1.17 \pm 0.80 \%$ in the first, second, and third mineral layer respectively (Fig. 3 and Tables 4 and 5 in Annex 2). $\mathrm{BD}_{1}$ averaged $0.71 \pm 0.14 \mathrm{~g}$ $\mathrm{cm}^{-3}$, increasing in the second investigated layer to $1.16 \pm$ $0.18 \mathrm{~g} \mathrm{~cm}^{-3}$. The average $\mathrm{pH}_{w}$ value of the first layer was $5.2 \pm 0.8$, remaining stable in the second layer, and increasing to $5.9 \pm 0.7$ in the third layer. $\mathrm{C}: \mathrm{N}$ ratios were similar for all the investigated layers, averaging 13.3. The average $\mathrm{P}_{\mathrm{av}}$ content was $10.82 \pm 4.94 \mathrm{mg} \mathrm{kg}^{-1}$. No significant differences among forest types were found in $\mathrm{P}_{\mathrm{av}}$ and SOC at Bosco Vacaressino, but the type of organic matter (as shown by $\mathrm{C}: \mathrm{N}$ values) soil reaction, and $\mathrm{BD}_{1}$ discriminated red oak forest from mixed forest (Fig. 3 and Tables 4 and 5 in Annex 2).

In the mixed forest at Bosco Ginestre, the SOC of the mineral soil was high in the first two layers, averaging 4.85 $\pm 1.58 \%$ and $1.54 \pm 0.34 \%$, respectively, and decreased to $0.94 \pm 0.27 \%$ in the 35-60-cm layer (Fig. 4 and Tables 4 and 5 in Annex 2); $\mathrm{pH}_{\mathrm{w}}$ value was $4.4 \pm 0.2$ in the surface mineral layer slightly increasing with depth. The $\mathrm{C}: \mathrm{N}$ ratio was $15.7 \pm 0.9$ until a depth of $35 \mathrm{~cm}$. The average $\mathrm{P}_{\mathrm{av}}$ was 
$14.1 \pm 5.5 \mathrm{mg} \mathrm{kg}^{-1}$, ranging between 4.7 and $22.1 \mathrm{mg} \mathrm{kg}^{-1}$. $\mathrm{BD}$ was $0.83 \pm 0.19 \mathrm{~g} \mathrm{~cm}^{-3}$ in the $0-10-\mathrm{cm}$ layer and $1.17 \pm$ $0.12 \mathrm{~g} \mathrm{~cm}^{-3}$ in the $10-35-\mathrm{cm}$ layer.

SOC was higher in red oak forest than in mixed forest; the first layer showed an average value of $5.5 \pm 1.9 \%$ but no statistical differences were found between the two forest types, differently from the second layer where SOC was statistically higher in red oak forest. The third layer showed an average SOC not different from that of the mixed forest (Fig. 4 and Tables 4 and 5 in Annex 2). Statistical differences between the two vegetation cover types were also found in $\mathrm{pHw}_{1}(p<0.05)$ and $\mathrm{CN}_{1}(p<0.1)$, lower and higher, respectively, in red oak forest than in mixed forest.

The third investigated layer showed similar soil characteristics in both forest types of each investigated site, suggesting a non-involvement of deep soil layer in forest conversion effects. For this reason, only the $\mathrm{SOC}_{\text {stock }}$ of the first two layers together, by comparing equivalent soil mass, was considered. At the Bosco Vacaressino, the $\mathrm{SOC}_{\text {stock }}$ of the two forest types was not statistically different, while at Bosco Ginestre, red oak forest showed an average value of $12.04 \mathrm{~kg} \mathrm{~m}^{-2}$ (ranging between 9.8 and $15.7 \mathrm{~kg} \mathrm{~m}^{-2}$ ), statistically higher than that of mixed forest $\left(8.31 \pm 2.83 \mathrm{~kg} \mathrm{~m}^{-2}\right)$.

\section{Discussion}

\subsection{Site comparability and spatial variability}

Reliable evaluations of changes in soil characteristics due to changes in vegetation cover are possible if the comparability of sites is guaranteed. However, the spatial variability that characterizes the soil properties increases the uncertainty of such estimates, especially when dealing with forest ecosystems where soil variability is even more accentuated by heterogeneity in tree and shrub composition (Ferré et al. 2014; Kounda-Kiki et al. 2008). To satisfy the requirements for assessing the impact of vegetation cover changes on humus forms and soil properties, we selected the two sites because each of them includes both mixed and red oak forest stands with comparable land use history until time of conversion, and same pedological conditions. Since soil texture does not depend on the forest type but on the nature of the parent material from which the soil has developed, the common pedological origin of soils within each study site was verified and confirmed by soil texture comparability. For both sites, the texture (USDA class) of the subsoil was mainly sandy loam with no differences between red oak forest and mixed forest.

The detailed sampling performed at the study sites enabled considering the spatial variability in humus forms and soil properties, ensuring the representativeness of the obtained results. Considerable variability in humus forms and soil properties was found not only in each paired plot, but also within each forest stand. The spatial distribution of the organic and mineral layer properties probably reflected the heterogeneity of forest vegetation, particularly in mixed forest, where species were various and scattered in all forest layers. Often, a spatial structure of residuals was not found, due to an inherent variability on a spatial scale shorter than that of the measurements.

\subsection{Effects of forest conversion on humus forms and organic horizon carbon stock}

Replacing mixed oak-hornbeam forest with red oak forest caused a shift from Mull to Moder forms (Gentili et al. 2019) mainly as a consequence of a recalcitrant litter in red oak forest types (Jonczak et al. 2015). Decomposition of plant litter is a complex process which is controlled by climate, litter quality, and microbial communities (Couteaux et al. 1995; Regina and Tarazona 2001). In our case, in which we may safely exclude climate as factor of variation, litter quality mainly influenced the decomposition rate, but also the dynamics of nutrient mineralization and immobilization (Regina and Tarazona 2001), which in turn may have affected microbial communities (Graça and Poquet 2014) directly involved in litter decomposition. Some studies reported relationships between the rate of leaf litter decomposition and leaf litter C:N ratios (Hobbie 2015; Steffen et al. 2007). The effects of litter chemistry on microbial activity also involve the role of polyphenolic compounds (Steltzer and Bowman 2005). In particular, concerning red oak, Talbot and Finzi (2008) observed that litter tannins, during periods of large protein inputs (following root turnover, or after leaf senescence), play an important role in lowering the rate of soil nutrient cycling by binding proteins into recalcitrant complexes.

Evaluating the effect of the introduction of red oak in areas of mixed broadleaved forests of northwestern Italy, Bonifacio et al. (2015) found a relationship between the different transformation of organic layers of the compared forest types and differences in litter biochemical composition consisting of a larger presence of tannins and a higher aromatic $\mathrm{C} / \mathrm{O}$-alkyl $\mathrm{C}$ and alkyl C/O-alkyl $\mathrm{C}$ ratios, which were indicative of lower degree of litter decomposition, in red oak forests than in native forests.

The Intergovernmental Panel on Climate Change recognized litter carbon as one of five $\mathrm{C}$ pools in forest ecosystems included in the Agriculture, Forestry, and Other Land Use sector of the annual national greenhouse gas inventories (IPCC 2006). The litter layer accounts for about $5 \%$ of all forest ecosystem carbon stocks worldwide (Pan et al. 2011), so changes in the litter carbon pool have important implications for global carbon budgets. The presence of the complete sequence of organic horizons (OL, OF, and $\mathrm{OH})$, visible in part of the red oak forest at Bosco Vacaressino and in most of the red oak forest at Bosco Ginestre, and the significantly higher OC in red oak forest of both study areas, supported the lower turnover of red oak organic matter and the capacity of red oak forest organic layers to act as a carbon sink. As a consequence of 50 years of red oak persistence, we found an 
increase in $\mathrm{OC}_{\mathrm{O}}$ of about $50 \%$ compared with the natural mixed forest, whereas in the 80 -year-old red oak forest, the $\mathrm{OC}_{\mathrm{O}}$ almost tripled with respect to $\mathrm{OC}_{\mathrm{O}}$ of the mixed forest. The shift of humus forms toward a decrease in biological activity was more emphasized at Bosco Ginestre compared with the Bosco Vacaressino site: in the older red oak forest, in addition to higher accumulation of $\mathrm{OC}$ in the organic layers, substantial increases in Hum $_{\text {ind }}$ were also observed, in accordance with what was reported by Ponge and Chevalier (2006), who found a positive relationship between the Humus index and the age of forest stands.

\subsection{Effects of forest conversion on mineral layers}

The conversions from mixed to red oak forests affected the mineral topsoil, although, concerning some parameters, to a lesser extent than humus forms, since changes in soil characteristics are much slower than changes in humus forms as suggested by some space-for-time studies (Bernier and Ponge 1994; Dimbleby 1962; Willis et al. 1997).

Soil acidification occurred in red oak forest at both sites. Similarly, Miltner et al. (2016) found a decrease in $\mathrm{pH}_{\mathrm{w}}$ values when investigating the effects of red oak on soil properties at forest sites in the Czech Republic. In particular, in Moder forms like those that predominantly characterized the ROF at the Bosco Ginestre site and part of red oak forest at the Bosco Vacaressino site, most of microbial biomass is fungal due to the more acidic conditions than in Mull (Nagel-de-Boois and Jansen 1967). Fungi produce antibiotics, leading to breakage of bacteria and excrete organic acids resulting in further acidification of the soil (Takao 1965). However, lowering of soil $\mathrm{pH}_{\mathrm{w}}$ due to "acidifying" red oak litter was particularly marked in originally less acid soils probably due to the fact that the acidification trend of a soil decreases at lower soil $\mathrm{pH}$ (Wiklander and Andersson 1972).

Moder humus forms are generally characterized by smaller, lower abundance, and lower diversity macrofauna compared with Mull humus forms (Schaefer 1991). The biological activity of organic matter was lower in red oak forest compared with mixed forest, resulting in organic matter accumulation and slower incorporation into the mineral soil. For the 50year-old red oak forest, vegetation effects on organic carbon stock were observed only in organic horizons; for the 80-yearold red oak forest, effects of vegetation were visible in the mineral soil, too. As a consequence of 80 years of red oak forest, we found an increase in soil $\mathrm{SOC}_{\text {stock }}$ of about $45 \%$ compared with the native forest.

Vegetation conversion also affected soil organic matter quality as shown by the higher soil $\mathrm{C}: \mathrm{N}$ ratio in red oak forests than in mixed forests. Similar to our findings but concerning the spruce forests in the Italian Alps, Salmon et al. (2006) found increases in soil carbon content and C:N ratio that were accentuated in mature spruce stands compared with younger ones.

Different from what was reported in previous studies (Bonifacio et al. 2015; Miltner et al. 2016), we found no difference between forest types in the $\mathrm{P}_{\mathrm{av}}$ of the investigated mineral layers. This finding could be related to the fact that the spatial distribution of this soil characteristic was highly variable.

\section{Conclusions}

We studied the effects of afforestation with red oak on humus forms and soil properties in two paired plots through a sampling scheme that considered the horizontal and vertical spatial variability to ensure representativeness of the obtained results. The comparability of soil properties between the two neighboring forests was guaranteed by performing soil sampling by depth increments and, concerning SOC stock, by comparing equivalent soil masses.

Besides the well-known effects of red oak on the native plant community, whose structure is altered and biodiversity is significantly reduced in tree, shrub, and herbaceous layer, this alien species may also impact the soil. In forest management aimed at the establishment of red oak plantations, it is important to take into account that, if on the one hand, the recalcitrant nature of the litter favors the accumulation of the organic residues on topsoil, promoting the carbon sink role of soil, on the other hand, it inhibits the processes of transformation and incorporation of the organic matter into mineral soil, which occur more slowly than in native forests, and favors mineral soil acidification.

In detail, major changes in soil characteristics mainly involved organic layers: vegetation changes were reflected in changes in litter quantity and quality. The substitution of natural mixed forest by red oak forest strongly changed organic horizons, resulting in a shift of humus forms from Mull to Moder, i.e., a shift toward less active humus forms.

The effects of vegetation conversions were also visible in mineral layers: soil acidification, increase in $\mathrm{C}: \mathrm{N}$ ratio, reflecting change in organic matter characteristics toward a quality worsening, and higher $\mathrm{SOC}_{\text {stock }}$ in red oak forest compared with mixed forest were observed. Many of the detected modifications, whether they involved organic or mineral horizons, increased according to stand age. Although a wider range of investigated tree ages would permit a better assessment of age impact, we observed that the changes in the humus forms and associated parameters, such as organic matter accumulation in the topsoil and increase in SOC stock, were more evident with increasing time elapsed from the red oak forest establishment. 


\section{Annexes}

\section{Annex 1}
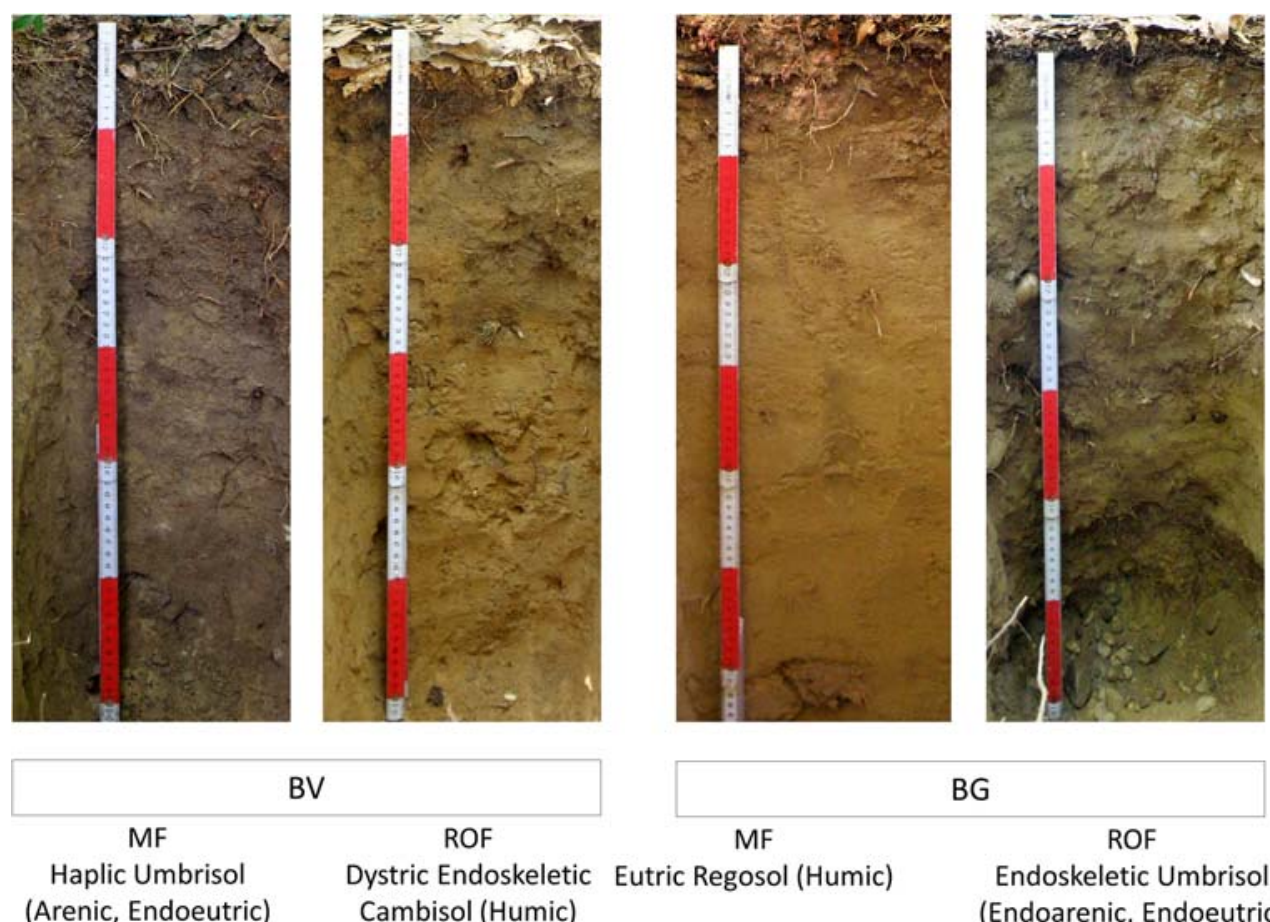

BV (Arenic, Endoeutric)

\section{ROF}

Dystric Endoskeletic Eutric Regosol (Humic) Cambisol (Humic)

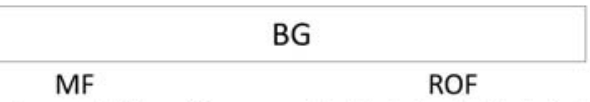

Endoskeletic Umbrisol

(Endoarenic, Endoeutric)

Fig. 5 Soil profiles of mixed forest (MF) and red oak forest (ROF) at study sites Bosco Vacaressino (BV) and Bosco delle Ginestre (BG). Taxonomy of soil profiles according to IUSS Working Group WRB (2015)

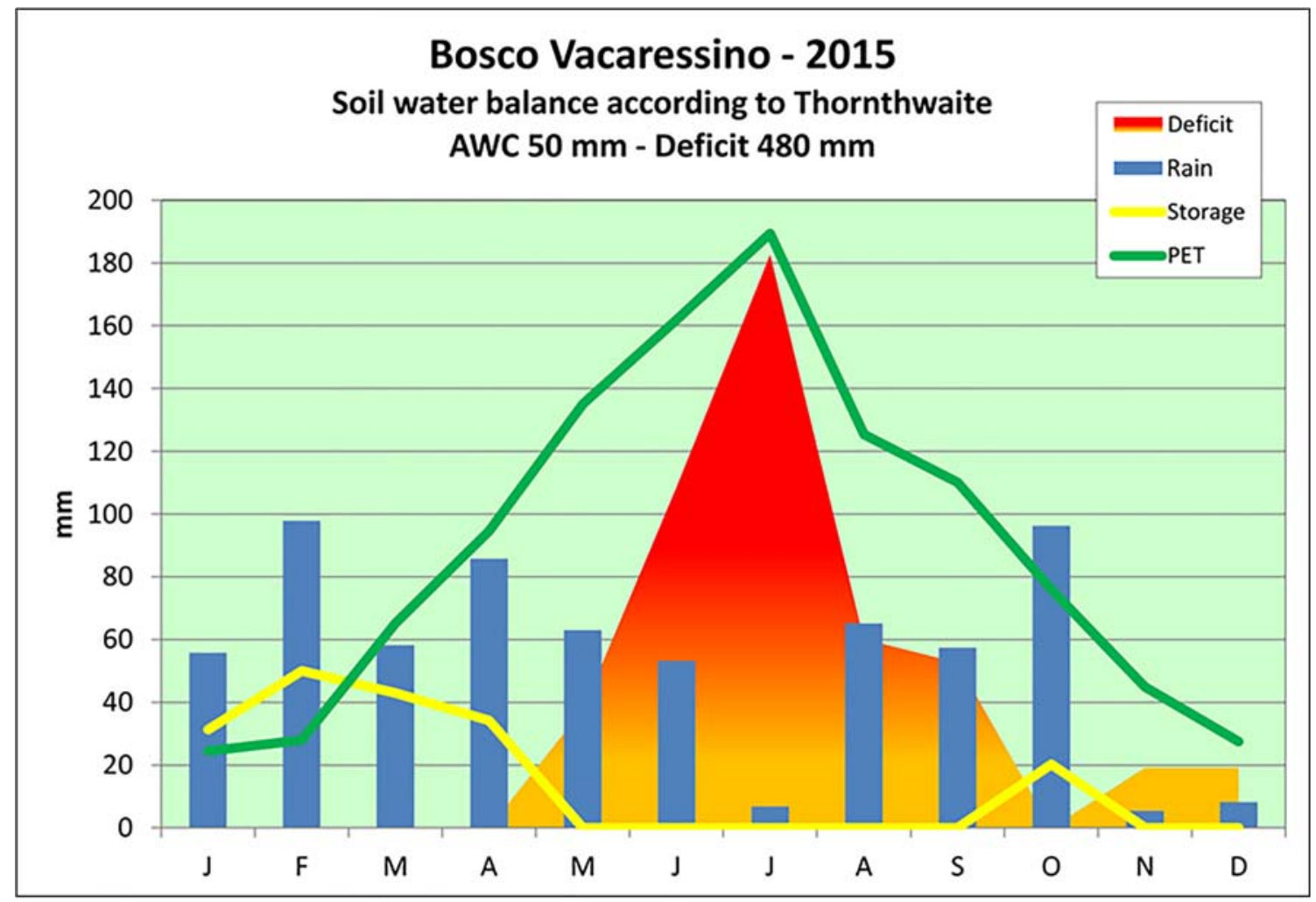

Fig. 6 Soil water balance according to Thornthwaite for Bosco Vacaressino

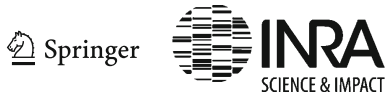




\section{Annex 2}

Table 2 Soil profile descriptions. Taxonomy of soil profiles according to IUSS Working Group WRB (2015)

\begin{tabular}{|c|c|c|c|c|c|}
\hline Profiles and horizons & Color (moist) & Mottles & Rock fragments & Structure & Roots \\
\hline \multicolumn{6}{|c|}{ BV (Bosco Vacaressino) } \\
\hline \multicolumn{6}{|c|}{ MF (mixed forest)—Haplic Umbrisol (Arenic, Endoeutric) } \\
\hline A $(0-3 \mathrm{~cm})$ & $10 \mathrm{YR} 2 / 2$ & Absent & Common, $\mathrm{f}-\mathrm{vf}$ & Granular, $\mathrm{m}$ & Many, $\mathrm{f}-\mathrm{vf}$ \\
\hline $\mathrm{AB}(3-27 \mathrm{~cm})$ & $10 Y R 3 / 3$ & Absent & Frequent, $\mathrm{f}-\mathrm{vf}$ & Subang. blocky, m & Common, vf-f \\
\hline $\mathrm{BC}(27-60 \mathrm{~cm})$ & $10 Y R 4 / 4$ & Absent & Frequent, $\mathrm{f}-\mathrm{vf}$ & Massive & Few, $\mathrm{f}-\mathrm{m}$ \\
\hline \multicolumn{6}{|c|}{ ROF (red oak forest)—Dystric Endoskeletic Cambisol (Humic) } \\
\hline A $(0-2 \mathrm{~cm})$ & $10 \mathrm{YR} 2 / 2$ & Absent & Few, $\mathrm{f}-\mathrm{vf}$ & Single grain & Many, $\mathrm{f}-\mathrm{vf}$ \\
\hline $\mathrm{AB}(2-13 \mathrm{~cm})$ & 10 YR $3 / 3$ & Absent & Few, f-vf & Granular, m & Common, $\mathrm{f}-\mathrm{vf}$ \\
\hline $\mathrm{Bw}(13-33 \mathrm{~cm})$ & $10 Y R 4 / 5$ & Absent & Few, f-vf & Subang. blocky, m & Common, $\mathrm{f}-\mathrm{m}$ \\
\hline BC $(33-60 \mathrm{~cm})$ & 10YR 3.5/6 & 10YR 6/6, many & Abundant, $\mathrm{f}-\mathrm{vf}$ & Massive & Few, m \\
\hline \multicolumn{6}{|l|}{ BG (Bosco Ginestre) } \\
\hline \multicolumn{6}{|c|}{ MF (mixed forest)—Eutric Regosol (Humic) } \\
\hline A $(0-9 \mathrm{~cm})$ & 10YR 3/2.5 & Absent & Absent & Granular, $\mathrm{f}$ & Many f-vf \\
\hline $\mathrm{AC}(9-20 \mathrm{~cm})$ & $10 \mathrm{YR} 4 / 3$ & Absent & Absent & Subang. blocky, m & Common, vf-f \\
\hline $\mathrm{C} 1(20-35 \mathrm{~cm})$ & $10 Y R 4.5 / 3$ & Absent & Absent & Subang. blocky, m & Few, vf \\
\hline $\mathrm{C} 2(35-77 \mathrm{~cm})$ & 10YR 5/4 & Absent & Absent & Subang. blocky, m & Few, $\mathrm{f}-\mathrm{c}$ \\
\hline C3 $(77-90 \mathrm{~cm})$ & 10 YR $5 / 3$ & Absent & Absent & Single grain & Absent \\
\hline \multicolumn{6}{|c|}{ ROF (red oak forest) —Endoskeletic Umbrisol (Endoarenic, Endoeutric) } \\
\hline $\mathrm{A}(0-10 \mathrm{~cm})$ & $10 \mathrm{YR} 3 / 3$ & Absent & Frequent, $\mathrm{f}-\mathrm{vf}$ & Subang. blocky, f & Common, $\mathrm{f}-\mathrm{vf}$ \\
\hline $\mathrm{AC}(10-35 \mathrm{~cm})$ & 10 YR $3 / 3$ & Absent & Frequent, $\mathrm{f}-\mathrm{vf}$ & Subang. blocky, m & Common, $\mathrm{f}-\mathrm{vf}$ \\
\hline $\mathrm{C} 1(35-50 \mathrm{~cm})$ & $10 Y R 4 / 4$ & Absent & Frequent, $\mathrm{f}-\mathrm{vf}$ & Single grain & Few, $\mathrm{f}-\mathrm{vf}$ \\
\hline $\mathrm{C} 2(50-65 \mathrm{~cm})$ & 10YR 5/4 & Absent & Abundant, v-vf & Single grain & Few, vf \\
\hline
\end{tabular}

$v f$, very fine; $f$, fine; $m$, medium; $c$, coarse; $v c$, very coarse 


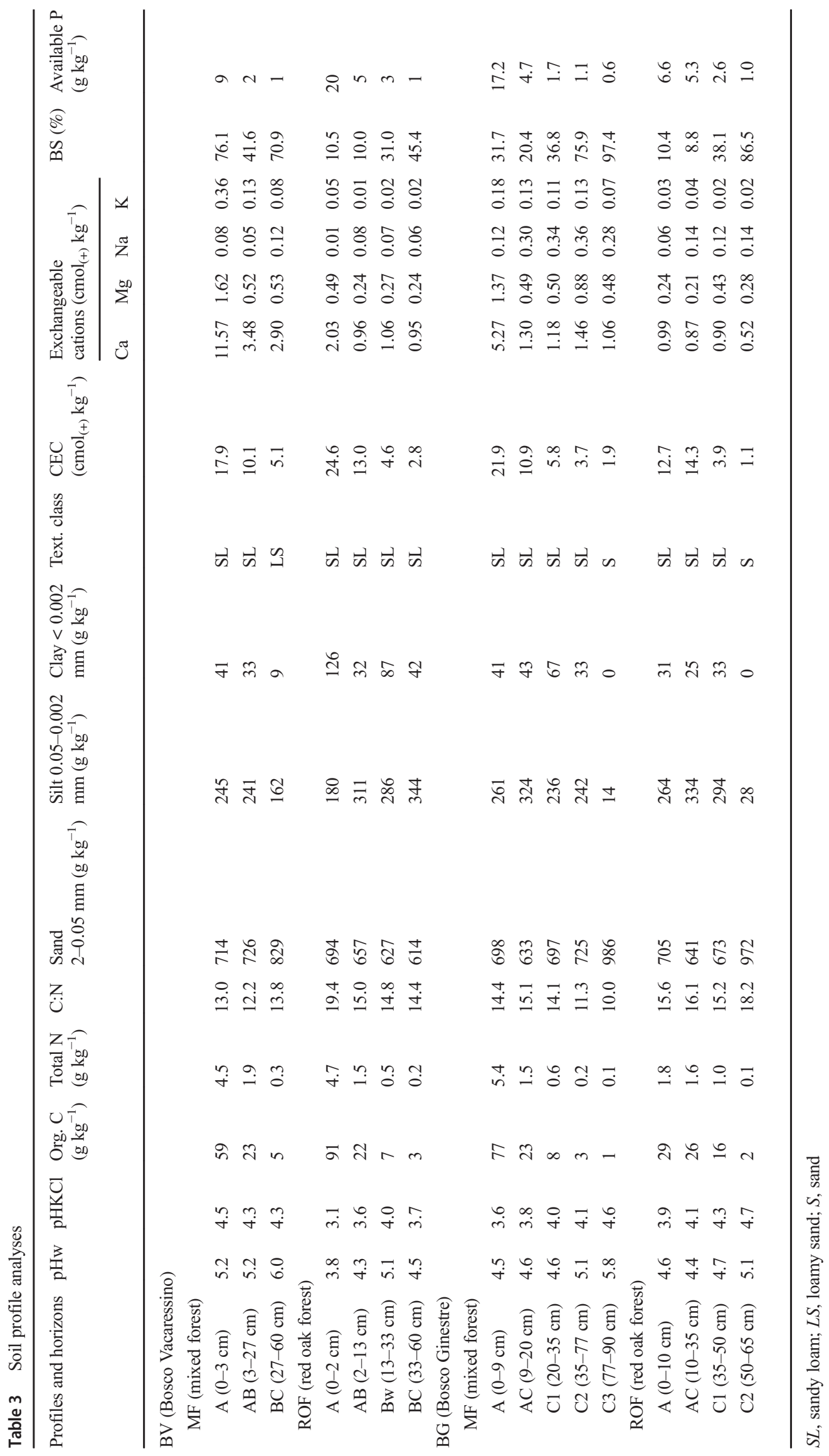




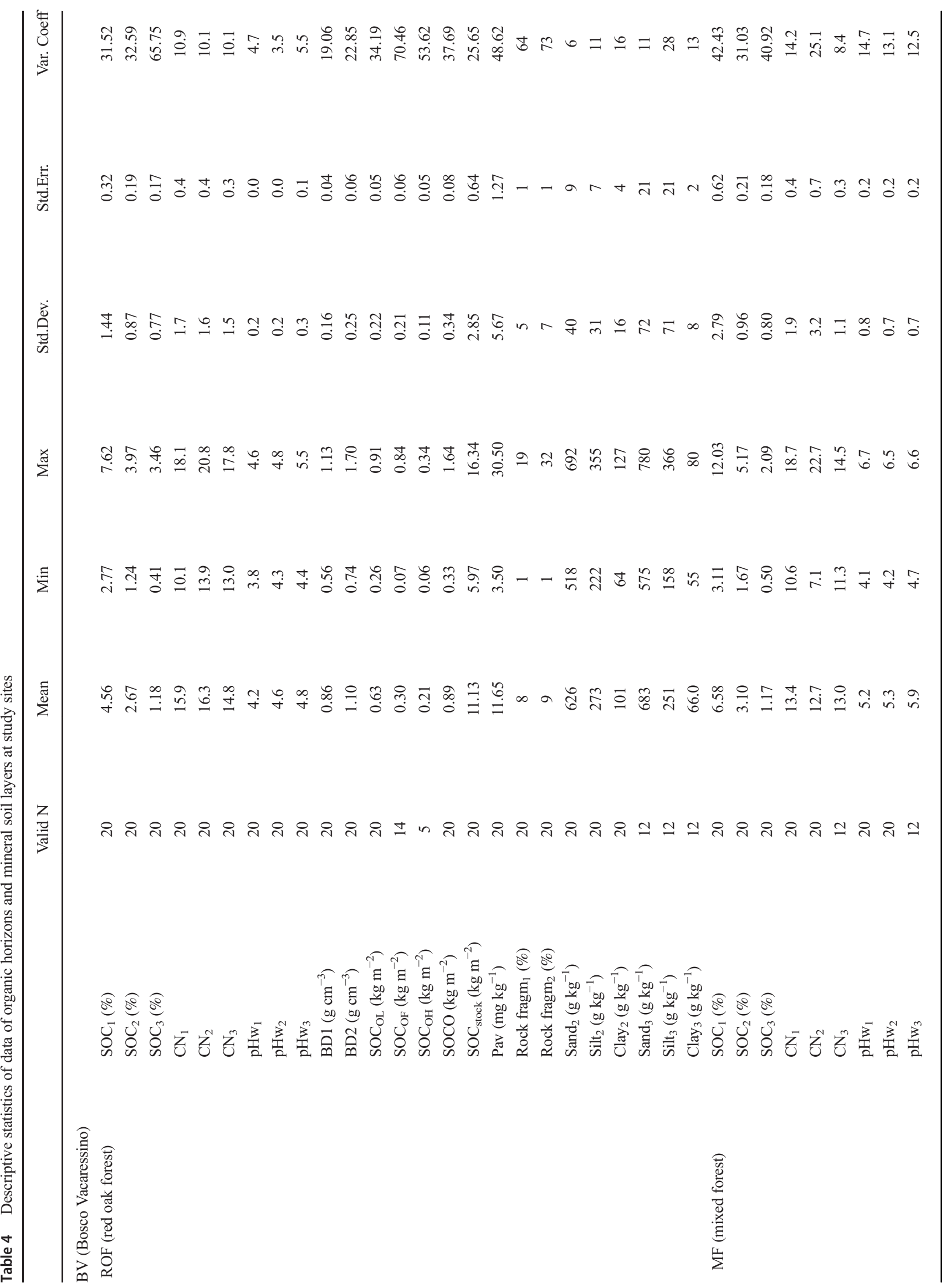




\begin{tabular}{|c|c|c|}
\hline 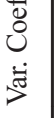 & 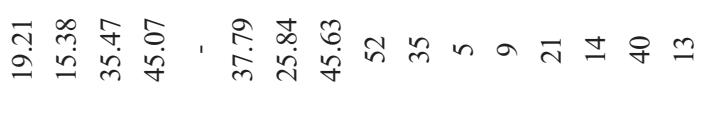 & 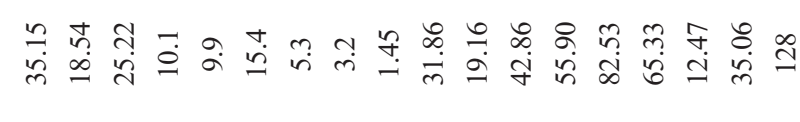 \\
\hline 焉 & 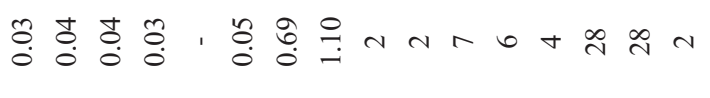 & గొં \\
\hline 苛 & 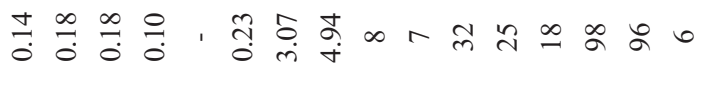 & 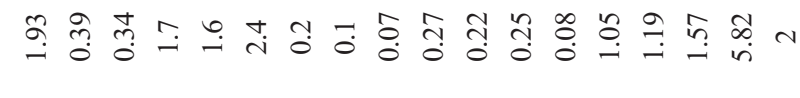 \\
\hline$\sum_{\Sigma}^{\stackrel{\star}{\Sigma}}$ & 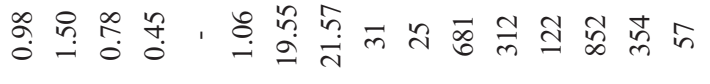 & 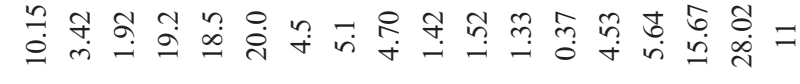 \\
\hline$\dot{\Xi}$ & 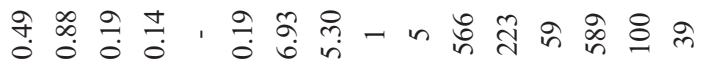 & 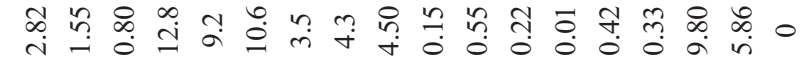 \\
\hline$\sum_{\Sigma}^{\frac{0}{\Sigma}}$ & 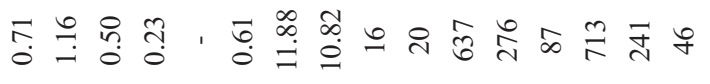 & 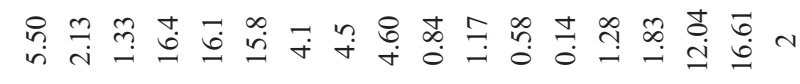 \\
\hline $\bar{\Xi}$ & ন ন ণ্స & 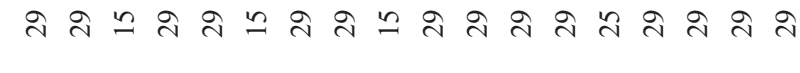 \\
\hline & 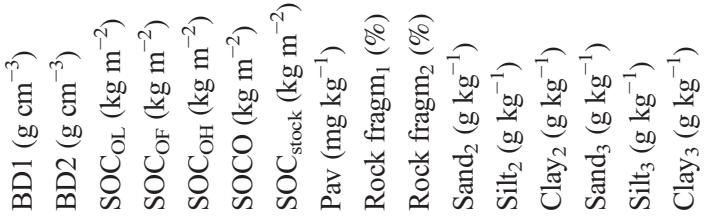 & 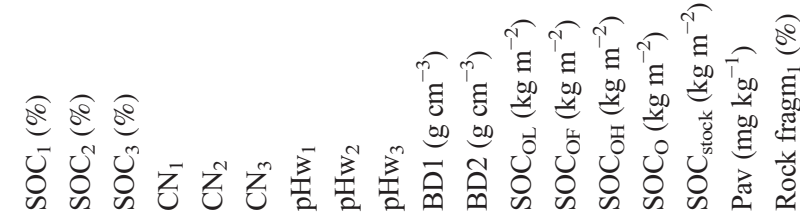 \\
\hline & & 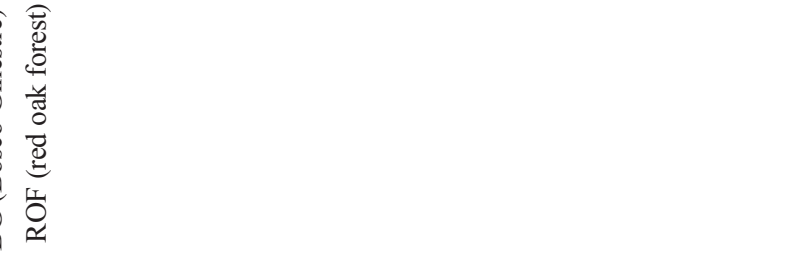 \\
\hline
\end{tabular}




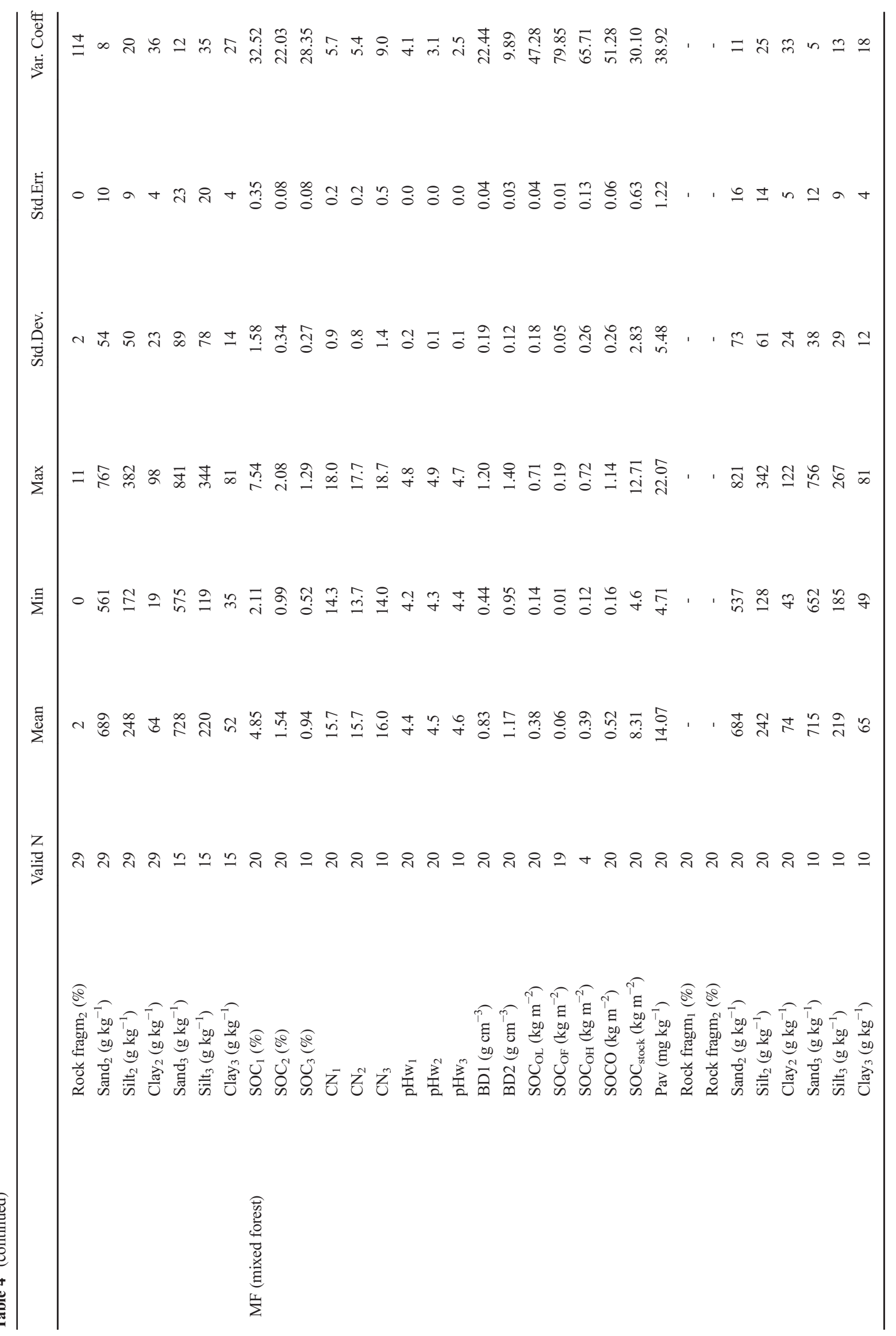




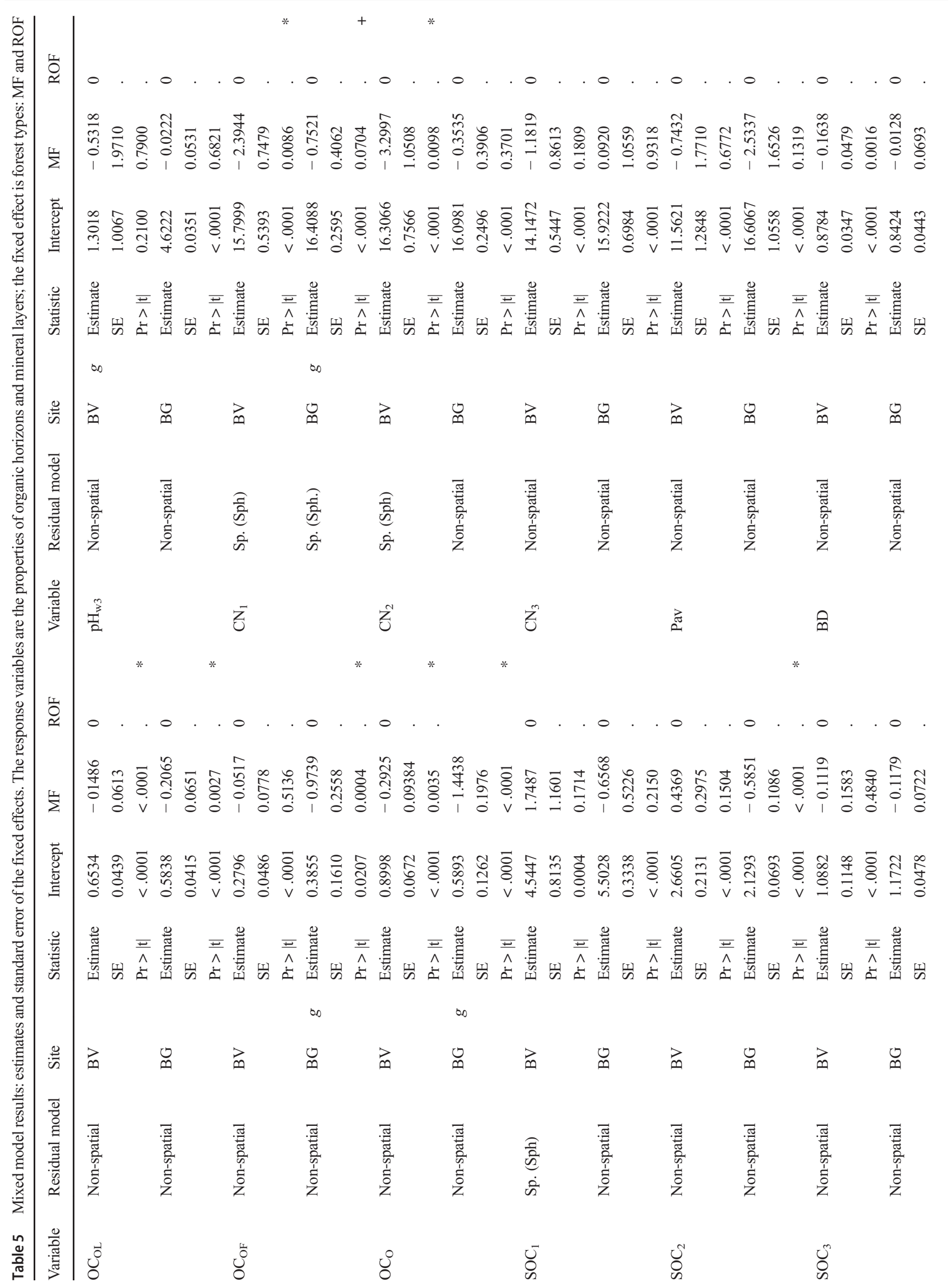




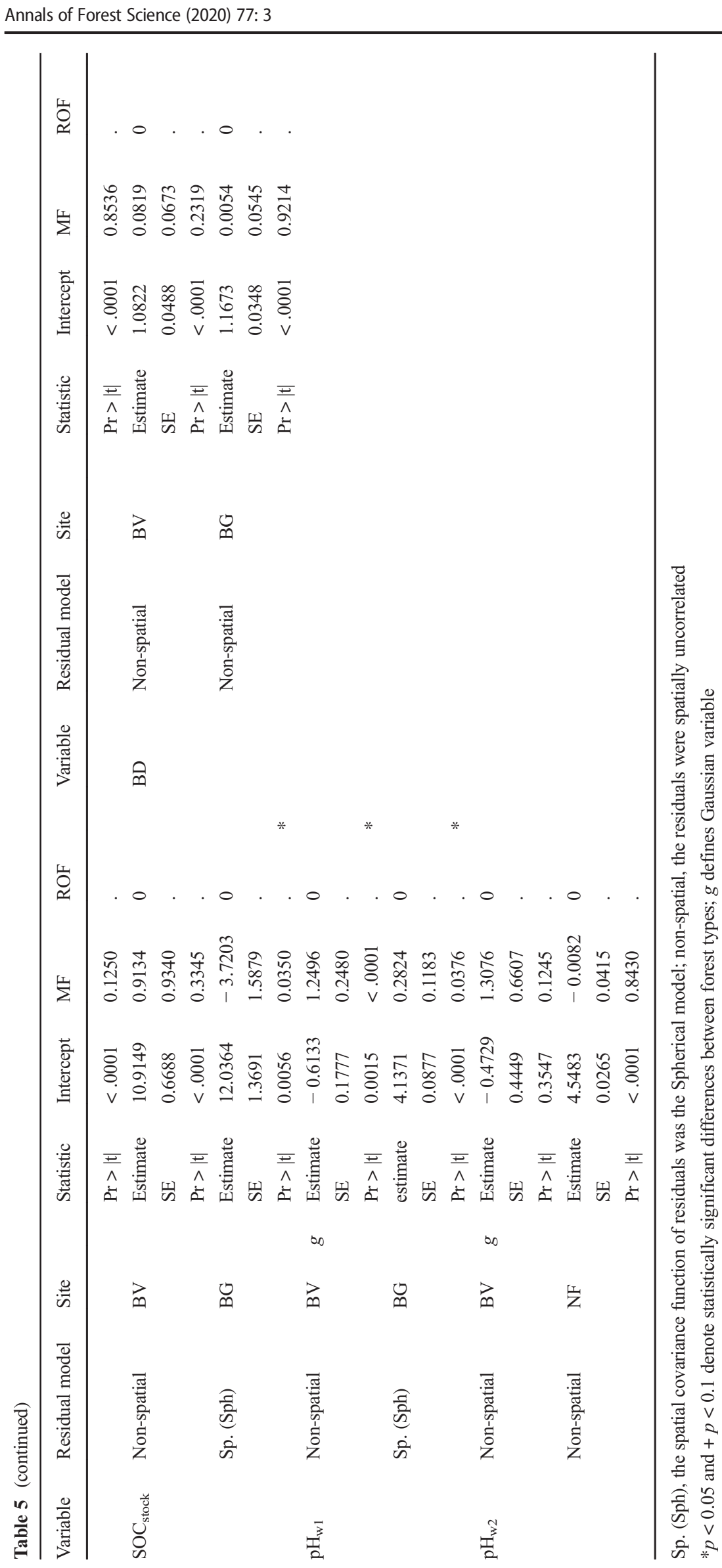

Page 17 of $19 \quad 3$ 
Acknowledgments We received substantial help from F. Caronni (Ticino Park). We thank to F. Concas, L. Naldi, D. Codenotti, D. Abu El Khair, and L. Ballabio for their help with field and laboratory work. A special thanks to A. Castrignanò (Unit for Cropping Systems in Dry Environments, CREASCA, Bari) for her kind support in geostatistical analyses.

Data availability The datasets generated and analyzed during the current study are available in the Pangaea repository (Ferré and Comolli 2019) at https://doi.pangaea.de/10.1594/PANGAEA.905854.

\section{Compliance with ethical standards}

Conflict of interest The authors declare that they have no conflict of interest.

\section{References}

Bernier N, Ponge JF (1994) Humus form dynamics during the sylvogenetic cycle in a mountain spruce forest. Soil Biol Biochem 26:183-220. https://doi.org/10.1016/0038-0717(94)90161-9

Bohn U, Neuhäusl R, Gollub G, Hettwer C, Neuhäuslová Z, Raus T, Schlüter H, Weber H (2000) Karte der natürlichen Vegetation Europas (Map of the natural vegetation of Europe). Maßstab / Scale 1: 2500 000. Landwirtschaftsverlag, Münster

Bolker BM, Brooks ME, Clark CJ, Geange SW, Poulsen JR, Stevens MHH, White J-SS (2009) Generalized linear mixed models: a practical guide for ecology and evolution. Trends Ecol Evol 24:127-135. https://doi.org/10.1016/j.tree.2008.10.008

Bonifacio E, Petrillo M, Petrella F, Tambone F, Celi L (2015) Alien red oak affects soil organic matter cycling and nutrient availability in low-fertility well-developed soils. Plant Soil 395:215-229. https:// doi.org/10.1007/s11104-015-2555-9

Burt R (2004) Soil survey laboratory methods manual. Soil Survey Investigation Report No 42, version 4.0. USDA-NRCA, Lincoln, $\mathrm{NE}$

Chmura D (2013) Impact of alien tree species Quercus rubra L. on understorey environment and flora: a study of the Silesian Upland (Southern Poland). Pol J Ecol 61:431-442

Couteaux MM, Bottner P, Berg B (1995) Litter decomposition, climate and litter quality. Trends Ecol Evol 10:63-66. https://doi.org/10. 1016/S0169-5347(00)88978-8

Dimbleby GW (1962) The development of British heathlands and their soil. Oxford Forestry Memoirs, vol 23. Clarendon Press, Oxford

Ehrenfeld JG (2003) Effects of exotic plant invasions on soil nutrient cycling processes. Ecosystems 6:503-523. https://doi.org/10.1007/ s10021-002-0151-3

Ellert BH, Bettany JR (1995) Calculation of organic matter and nutrients stored in soils under contrasting management regimes. Can J Soil Sci 75:529-538. https://doi.org/10.4141/cjss95-075

Ferré C, Comolli R (2019) Soil properties and humus forms in 50-year old and 80-year Red oak stands and native mixed forests of Lombardy plain. PANGAEA. [Dataset]. https://doi.org/10.1594/ PANGAEA.905854

Ferré C, Comolli R, Leip A, Seufert G (2014) Forest conversion to poplar plantation in a Lombardy floodplain (Italy): effects on soil organic carbon stock. Biogeosciences 11:6483-6493. https://doi.org/10. 5194/bg-11-6483-2014

Gentili R, Ferré C, Cardarelli E, Montagnani C, Bogliani G, Citterio S, Comolli R (2019) Comparing negativeimpacts of Prunus serotina, Quercus rubra and Robinia pseudoacacia on native forest ecosystems. Forests 10:842. https://doi.org/10.3390/f10100842
Graça MAS, Poquet JM (2014) Do climate and soil influence phenotypic variability in leaf litter, microbial decomposition and shredder consumption? Oecologia 174:1021-1032. https://doi.org/10.1007/ s00442-013-2825-2

Hejda M, Pyšek P, Jarošík V (2009) Impact of invasive plants on the species richness, diversity and composition of invaded communities. J Ecol 97:393-403. https://doi.org/10.1111/j.1365-2745.2009. 01480.x

Hobbie SE (2015) Plant species effects on nutrient cycling: revisiting litter feedbacks. Trends Ecol Evol 30:357-363. https://doi.org/10. $1016 / j$. tree.2015.03.015

IPCC (2006) IPCC Guidelines for national greenhouse gas inventories. National Greenhouse Gas Inventories Programme, IGES, Japan

IUSS Working Group WRB (2015) World reference base for soil resources 2014, update 2015. World Soil Resources Reports, vol 106. FAO, Rome

Jonczak J, Parzych A, Sobisz Z (2015) Decomposition of four tree species leaf litters in headwater riparian forest. Balt For 21:133-143

Kounda-Kiki C, Ponge J-F, Mora P, Sarthou C (2008) Humus profiles and successional development in a rock savanna (Nouragues inselberg, French Guiana): a micro-morphological approach infers fire as a disturbance event. Pedobiologia 52:85-95. https://doi.org/10.1016/ j.pedobi.2008.04.002

Lenda M, Witek M, Skórka P, Moroń D, Woyciechowski M (2013) Invasive alien plants affect grassland ant communities, colony size and foraging behaviour. Biol Invasions 15:2403-2414. https://doi. org/10.1007/s10530-013-0461-8

Littell RC, Stroup WW, Milliken GA, Wolfinger RD, Schabenberger O (2006) SAS for mixed models, 2nd edn. SAS Institute Inc, Cary

Magni Diaz CR (2004) Reconstruction de l'introduction de Quercus rubra L. en Europe et conséquences génétique dans les populations allochtones, Phd Thesis, École National du Génie Rural, des Eaux et des Forêts, Paris

Miltner S, Kupka I, Třeštík M (2016) Effects of Northern red oak (Quercus rubra L.) and sessile oak (Quercus petraea (Mattusch.) Liebl.) on the forest soil chemical properties. Lesn Cas For J 62: 169-172. https://doi.org/10.1515/forj-2016-0020

Nagel-de-Boois H, Jansen E (1967) Hyphal activity in mull and mor of an oak forest. In: Graff O, Satchell JE (eds) Progress in Soil Biology. Vieweg, Braunschweig, pp 27-36

Olsen SR, Cole CV, Watanabe FS (1954) Estimation of available phosphorus in soils by extraction with sodium bicarbonate. Circular no. 939, United States Department of Agriculture, Washington

Pan Y, Birdsey RA, Fang J, Houghton R, Kauppi PE, Kurz WA, Phillips OL, Shvidenko A, Lewis SL, Canadell JG, Ciais P, Jackson RB, Pacala SW, McGuire AD, Piao S, Rautiainen A, Sitch S, Hayes D (2011) A large and persistent carbon sink in the world's forests. Science 333:988-993. https://doi.org/10.1126/science.1201609

Poeplau C, Don A, Vesterdal L, Leifeld J, van Wesemael B (2011) Temporal dynamics of soil organic carbon after land-use change in the temperate zone - carbon response functions as a model approach. Glob Chang Biol 17:2415-2427. https://doi.org/10.1111/j.13652486.2011.02408.x

Ponge J-F (2003) Humus forms in terrestrial ecosystems: a framework to biodiversity. Soil Biol Biochem 35:935-945. https://doi.org/10. 1016/S0038-0717(03)00149-4

Ponge J-F, Chevalier R (2006) Humus Index as an indicator of forest stand and soil properties. For Ecol Manag 233:165-175. https:// doi.org/10.1016/j.foreco.2006.06.022

Ponge J-F, Chevalier R, Loussot P (2002) Humus Index: an integrated tool for the assessment of forest floor and topsoil properties. Soil Sci Soc Am J 66:1996-2001. https://doi.org/10.2136/sssaj2002.1996

Ravazzi C, Marchetti M, Zanon M, Perego R, Quirino T, Deaddis M, De Amicis M, Margaritora D (2013) Lake evolution and landscape history in the lower Mincio River valley, unravelling drainage 
changes in the central Po Plain (N-Italy) since the Bronze Age. Quat Int 288:195-205. https://doi.org/10.1016/j.quaint.2011.11.031

Regina SI, Tarazona T (2001) Nutrient cycling in a natural beech forest and adjacent planted pine in northern Spain. Forestry 74:11-28. https://doi.org/10.1093/forestry/74.1.11

Riepsas E, Straigyte L (2008) Invasiveness and ecological effects of red oak (Quercus rubra L.) in lithuanian forests. Balt For 122-130

Salmon S, Mantel J, Frizzera L, Zanella A (2006) Changes in humus forms and soil animal communities in two developmental phases of Norway spruce on an acidic substrate. For Ecol Manag 237:4756. https://doi.org/10.1016/j.foreco.2006.09.089

Schaefer M (1991) Fauna of the European temperate deciduous forest. In: Röhrig E, Ulrich B (eds) Ecosystems of the world. VII. Temperate deciduous forests. Elsevier, Amsterdam, pp 503-525

Searle SR, Casella G, McCulloch CE (2009) Variance components. John Wiley \& Sons, Hoboken

Stefanowicz AM, Stanek M, Nobis M, Zubek S (2017) Few effects of invasive plants Reynoutria japonica, Rudbeckia laciniata and Solidago gigantea on soil physical and chemical properties. Sci Total Environ 574:938-946. https://doi.org/10.1016/j.scitotenv. 2016.09.120

Steffen KT, Cajthaml T, Snajdr J, Baldrian P (2007) Differential degradation of oak (Quercus petraea) leaf litter by litter-decomposing basidiomycetes. Res Microbiol 158:447-455. https://doi.org/10. 1016/j.resmic.2007.04.002

Steltzer H, Bowman WD (2005) Litter N retention over winter for a low and a high phenolic species in the alpine tundra. Plant Soil 275:361370. https://doi.org/10.1007/s11104-005-3100-z

Takao S (1965) Organic acid production by basidiomycetes. I. Screening of acid-producing strains. Appl Microbiol 13:732-737

Talbot JM, Finzi AC (2008) Differential effects of Sugar maple, Red oak, and Hemlock tannins on carbon and nitrogen cycling in temperate forest soils. Oecologia 155:583-592. https://doi.org/10.1007/ s00442-007-0940-7

Vansteenkiste D, de Boever L, van Acker J (2005) Alternative processing solutions for Red oak (Quercus rubra) from converted forests in
Flanders, Belgium. Proceedings of the COST Action E44 Conference on broad spectrum utilization of wood, Vienna

Vilà M, Espinar JL, Hejda M, Hulme PE, Jarošík V, Maron JL, Pergl J, Schaffner U, Sun Y, Pyšek P (2011) Ecological impacts of invasive alien plants: a meta-analysis of their effects on species, communities and ecosystems. Ecol Lett 14:702-708. https://doi.org/10.1111/j. 1461-0248.2011.01628.x

Wiklander L, Andersson A (1972) The replacing efficiency of hydrogen ion in relation to base saturation and $\mathrm{pH}$. Geoderma 7:159-165

Willis KJ, Braun M, Sümegi P, Tóth A (1997) Does soil change cause vegetation change or vice versa? A temporal perspective from Hungary. Ecology 78:740-750. https://doi.org/10.1890/00129658(1997)078[0740:DSCCVC]2.0.CO;2

Zanella A, Jabiol B, Ponge J-F, Sartori G, Waal R de, van Delft B, Graefe U, Cools N, Katzensteiner K, Hager H, Englisch M, Brêthes A, Broll G, Gobat J-M, Brun J-J, Milbert G, Kolb E, Wolf U, Frizzera L, Galvan P, Kõlli R, Baritz R, Kemmers R, Vacca A, Serra G, Banas D, Garlato A, Chersich S, Klimo E, Langohr R (2011) European humus forms reference base, http://hal.archivesouvertes.fr/docs/00/56/17/95/PDF/Humus_Forms_ERB_31_01_ 2011.pdf. Accessed 12 Sept 2019

Zanella A, Ponge J-F, Jabiol B, Sartori G, Kolb E, Le Bayon R-C, Gobat J-M, Aubert M, de Waal R, van Delft B, Vacca A, Serra G, Chersich S, Andreetta A, Kõlli R, Brun JJ, Cools N, Englisch M, Hager H, Katzensteiner K, Brêthes A, de Nicola C, Testi A, Bernier N, Graefe U, Wolf U, Juilleret J, Garlato A, Obber S, Galvan P, Zampedri R, Frizzera L, Tomasi M, Banas D, Bureau F, Tatti D, Salmon S, Menardi R, Fontanella F, Carraro V, Pizzeghello D, Concheri G, Squartini A, Cattaneo D, Scattolin L, Nardi S, Nicolini G, Viola F (2018) Humusica 1, article 5: Terrestrial humus systems and forms - keys of classification of humus systems and forms. Appl Soil Ecol 122:75-86. https://doi.org/10.1016/j.apsoil.2017.06.012

Publisher's note Springer Nature remains neutral with regard to jurisdictional claims in published maps and institutional affiliations. 